\title{
MALIGNANT MELANOMA OF THE CEREBELLO-PONTINE ANGLE REGION
}

\author{
F. MENEZES BRAGA - OSWALDO I. TELLA Jr. - ADELMO FERREIRA \\ $C E M E F . J O R D Y$
}

SUMMARY - A case of malignant melanoma in the cerebelio-pontine angle region is presentea in a 72 years old female patient, who had neurological examination and CT scan suggestive of acoustic neuroma. The surgical finding and the histological examination provided the diagnosis. As a primary focus was not found on clinical examination and although autopsy was not carried out, there is a possibility of the diagnosis being a primary malignant melanoma in CNS. This specific location for this kind of tumor was found to be rare when literature is looked up.

Melanoma maligno da regiăo do ângulo ponto-cerebelar.

RESUMO - Registro de caso de melanoma maligno na região do ângulo ponto-cerebelar em: pactente do sexo feminino, com 72 anos de idade, com exame neurológico e tomografia computadorizada sugestivos de neurinoma do acústico, em que o diagnóstico foi estabelecido pelo achado cirúr rico e pelo exame histopatológico. Como não foi achado foco primário no exame clínico e embora não tenha sido feita autopsia, hấ possibilidade de que o diagnóstico seja de melanoma maligno primário no sistema nervoso central. Esta localização particular desse tipo de tumor é considerada rara, levando em conta os dados da literatura.

Malignant melanoma generally occurs in the caucasian population $(98 \%)$, represents about $1 \%$ of the neoplasias in general, and is responsable for $1 \%$ of deaths due to neoplasias. The greatest incidence occurs between the ages of 35 and 50 , and after diagnosis one may expect a 5 year life expectancy in $67 \%$ of cases 13,41 . These tumors present a high degree of metastatization in all organs of the body, mainly in CNS, where they constitute the third commonest cause of metastasis $2,18,31$. Patients with skin melanomas may reveal 6 to $11 \%$ metastasis in the CNS during evolution, and this percentage may increase up to $90 \%$ in autopsies $2,31,43$. In the $\mathrm{SNC}$ metastasis occurs more frequently in the brain hemispheres 22 . The occurrence of primary malignant melanomas in the CNS has been reported to reach the pituitary, pineal gland, choroid plexus, cerebellum, cisterna magna and Sylvian fissure $9,17,21,34$, $36,37,39$. When primary they arise from melanocytes present in leptomeninges of the brain convexity or at the base, in the posterior fossa, in the spinal cervical canal, the coverings of the pia-mater vessels, the reticular formation of the pons and medulla, substantia nigra and locus coerulleus $21,24,25,45$. We report a case of a large malignant melanoma of the cerebello-pontine angle (CPA) with a very similar appearance of acoustic neuroma in the computerized tomography (CT). Although autopsy was not performed it could be a primary melanoma, as no other focus was detected.

\section{CASE REPORT}

IG, a 72 years oId female patient. started having vertigo and progressive deafness in the right ear about 18 months ago. More recently, two months ago, she developed gait disturbance with tendency to veer to the right side, mental deterioration, and loss of urine

Neurosurgical Department, Escola Paulista de Medicina, São Paulo.

Dr. F. Menezes Braga - Rua Cardoso de Mello Jr. 595 - 05462 São Paulo SP - Brasil. 
control. CT scan showed a large tumor in the CPA region with characteristics similar to acoustic neuroma (Fig. 1). There was a shift of the fourth ventricle and important supratentorial internal hydrocephalus. The internal auditory canal was slightly bigger on that side. Having cardiac insufficency she was submitted to a CSF shunt with local anaestesia. There was improvement of ataxia and of urine control for two months, after which she again starts presenting vertigo, and motor ataxia together with vomiting. On a new CT study the ventricles were small. The vomiting became constant, impairing her physical condition, she lost weight and was unable to stand up. It was decided to perform an inner decompression of the probable neuroma. The hematologic examination, chest $\mathrm{x}$ ray, glycemia

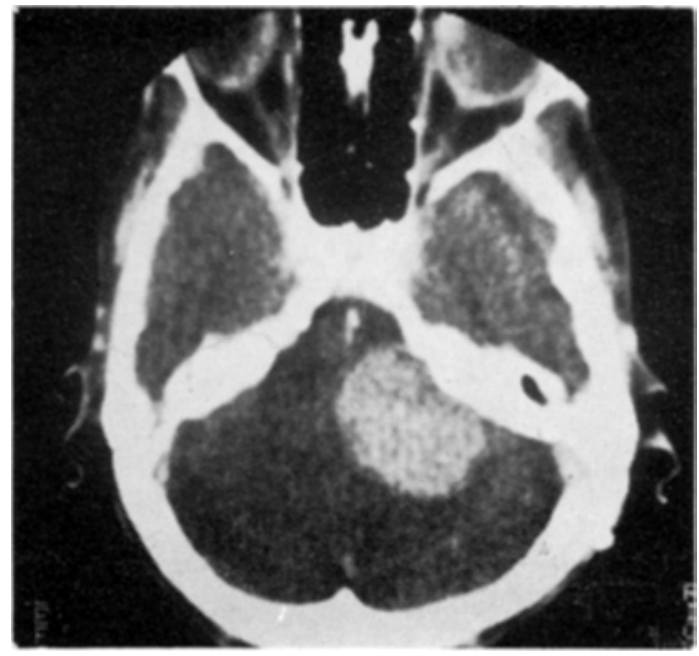

Fig. 1 - Case IG. CT scan: hypercaptant globous tumor with precise limits in the right cerebello-pontine congle.

and urea were normal. After cardiac compensation the patient was operated. In lateral position a craniectomy of the posterior fossa was made. It was found a big tumor with a dark aspect, thin capsule, extremely bloody, occupying the whole of the cerebello-pontine region, pressing on and deviating the brain stem, extending upward to the Pachioni foramen and downward enclosing the last cranial nerves. It penetrated into the internal acoustic canal, widening it and enclosing the nerves there. The proposed partial removal of the tumor was not possible since bleeding persisted until the whole tumor was removed. For the surgery a Laser was used. The last cranial nerves and the trigeninal one were saved but the facial and acoustic were damaged; the tumor was cureted from the internal acoustic canal. The main point of implantation of the tumor was in the duramater, a little bit lower than this canal. After surgery the patient had a good evolution till the third day when she developed a pulmonary edema and cardiac infartion, dying in the fifth post operative day. Necropsy was not permitted. Whilst still alive she was submitted to a detailed examination of the skin, mouth mucosa, eyes, genitalia and anus, without any positive finding for a primary focus of melanoma. The histologic examination showed a tumor composed of pleomorphic cells, with a fusiform aspect, having a big and hypercromatic nucleus and an eosinophilie cytoplasm containing pigment granules, some of them grouped around the vascular structures. The staining for iron pigments was negative. The diagnosis of malignant melanoma was made (Fig. 2).

\section{COMMENTS}

Malignant melanomas, due probably to hormonal difference, are more frequent in males in the proportion fo $2: 128$. In the CNS they may be metastatic or primary. Metastatic lesions develop by way of the bloodstream and CSF 35 . They are generally multiple 15 and occupy the brain tissue or meninges. They can be supra, infratentorial or located in the spinal canal. Lesions located in the head, neck, upper limbs, chest and face present a greater chance of producing metastasis in the CNS. Bullard et al.13 found in 86 autopsies of patients with melanoma metastasis in the CNS, the following picture: $48.8 \%$ were supratentorials (parietal frontal, occipital and temporal, in that order), $1.2 \%$ infratentorials, $3.3 \%$ in meninges, $9.3 \%$ in the 


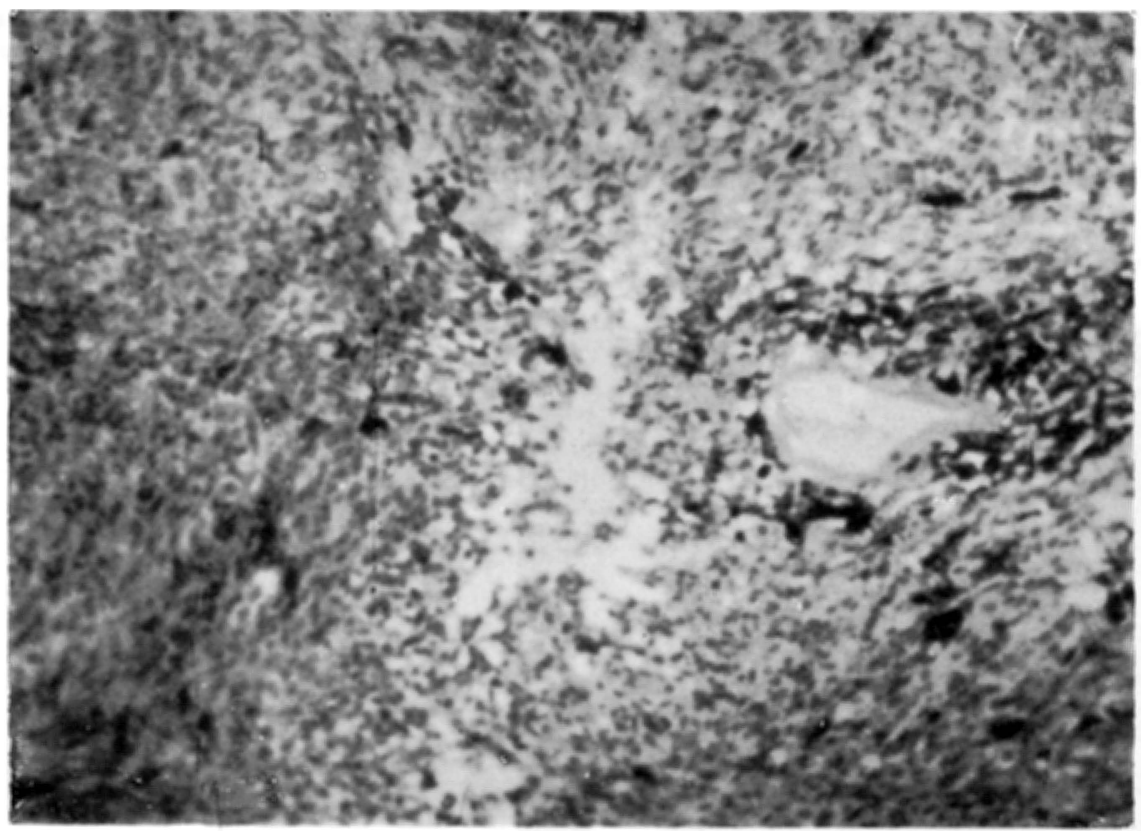

Fig. 2 - Case IG. Histopathology: unorganised proliferation of fusiform and round cells with large amounts of melanin pigment (HE, 200×).

spinal canal-cord and $37.2 \%$ were diffuse. Madajewicz et al.28 found in 66 autopsies $50 \%$ supratentorials, $4 \%$ infratentorials, $5 \%$ in the meninges and $44 \%$ diffuse. In $73 \%$ they were multiple, and single in $27 \%$.

As far as the primary melanoma in CNS is concerned, its presence was first described by Wirchow in 1859. This lesion is not frequent, has prolonged duration and rarely gives metastasis or dissemination outside the CNS 10,19,36,38. It is difficult to distinguish a primary lesion from a metastatic one, when single. In order to confirm a case as a primary melanoma one should have a necropsy, which must include an examination of the ocular chamber, not done in the majority of cases 37. These parameters, when followed, help in the differentiation of primary melanoma. A melanoma of the CNS can not be considered as primary when an ocular enucleation has been done, when a lesion has been cauterized or removed from the skin, when a cutaneous melanoma belongs to a region of lymphatic drainage and the skin has been treated, or when the anus and genitalia were not examined 14. According to these criteria, the incidence of primary melanoma in the CNS is about $4.4 \% 12,22$. The case we present may be primary as no suspected lesion was found. A detailed examination of the patient was done mainly because we already had a histologic diagnosis. The ideal study would be the necropsy but it was not accepted by the family. We examined the various chest $X$ rays of the patient and nothing was found related to a tumoral lesion.

Many locations in the CNS have been described for the melanomas: hypophysis, pineal gland, choroid plexus, cisterna magna and Sylvian fissure. In some cases whether or not they are primary or metastatic is questionable $4,9,17,34,37,39$. In our case the tumor was located in the CPA, and the similarity to the CT appearence of acoustic neuroma was striking. In an exhaustive research of the literature we found 6 cases described as malignant melanoma located in the CPA1,6,8,13,32,33, in which it was also difficult to distinguish if primary or metastatic, none having lesion outside the CNS. In 4 of these cases autopsies were done $6,8,13,33$. One of them cannot be considered as primary as lesion was discovered in the penis, which was subsequently amputated. In one case 1 autopsy was not done and in another 33 the patient was still alive at the time of the report, with no demonstration of lesion outside the CNS. 
Generally, the primary melanoma originates in the leptomeninges but it may originate in the paquimeninges as reported by Narayan et al.32. It is important to emphasize the possibility of other pigmented tumors in this region, which brings accurate diagnosis into doubt: pigmented Schwannomas which have been described in the 8 th nerve 16 , the mandible 23 , the spinal canal 7 , in association with meningeal melanosis 6, adamantimoma and von Recklinghausen 29 . They are slow growing tumors, that do not metastasize and have good prognosis. Histologically they are formed of fusiform cells with oval nuclei, sometimes arranged in palisade, with melanin present in the cytoplasm and in the extracellular space. These tumors present two distinct types of cells, Schwann cells and melanotic ones 7,16,29,40. Another tumor which can contain pigment is the melanotic meningeoma: 12 cases were described in the literature up to 198326 . It is formed by fusiform cells arranged in fascicles with oval nuclei, concentric nucleolus with chromatin and melanin granules present. The histological aspect recalls the fibroblastic meningeoma 27 . These may suffer malignant changes with the presence of mitosis, necrosis or hemorrhage, and may show quick growth, an infiltrative character and dissemination 26,27 . Another tumor is the pigmented medulloblastoma, also with two lineages of cells: one small with rounded and hyperchromatic nuclei, scarce cytoplasm and mitosis, and the other, ephitelial cells with pigment grouped around tubular structures, forming a significant part of the tumor 11,20,44. Histologically our case had the typical aspect of malignant melanoma without any possibility of confusion with the above described tumors. The melanomas frequently produce hemorrhages, that occur as a result of endothelial fenestrations of the capillaries, together with the fragility of the basal layer 46 . The hemorrhage may occur in the brain tissue or in the subarachnoid space. About 2 to $6 \%$ of the cases of subarachnoid hemorrhage are due to tumors, nainly from melanoma and the choriocarcinoma 3 . In the spontaneous intraparenchymatous hemorrhage, without any apparent cause, it is always important to do a biopsy of the surrounding tissue to exclude the possibility of this tumor 42 . The meningeal melanosis may also cause CSF blockage 24 .

When present in the CPA, malignant melanoma damages the nervous structures, manly the 8th nerve, as occurred with our patient and in the cases described in the literature. The presence of intracranial hypertension due to brain-stem compression or CSF blockage is common as well. In our case the intracranial hypertension was not evident and clinical signs suggested the normal pressure hydrocephalus syndrome, that improved after CSF shunt. Despite a CT scan having shown normal ventricles two months later, the patient got worse and this impairment was interpreted as being due to brain stem distortion by the tumor and then a posterior fossa exploration was performed despite her precarious clinical condition. There are no rigid criteria for surgery in cases of malignant melanoma of the CNS. A patient with one lesion in an accessible area should be submitted to surgical treatment, although having a short life expectancy 30 . Madajewicz et al.28 in 125 cases of brain melanomas, reported only 3 weeks survival in patients untreated, 6 weeks when receiving corticotherapy, 9 weeks when receiving radiotherapy, 11 weeks when treated with chemotherapy, and 25 weeks when surgery was carried out for a single metastasis 18,28.

Today in the treatment of malignant melanomas, corticotherapy, chemotherapy, immunotherapy, radiotherapy and surgery are used 28 . In our particular case death occurred after surgery and no other kind of treatment could be initiated.

\section{REFERENCES}

1. Albertengo JB - Melanoblastoma primitivo de fosa nosterior. Anales de Cirurgía $16: 224,1951$.

2. Amer MH. Sarraf MA, Baker LH, Vaitkvicius VK - Malignant melanoma and central nervous system metastases. Cancer 42:660, 1978.

3. Antunes ACM, Coutinho MF, Coutinho LBM - Hemorragias em metástases intracranianas de melanoma. Arq NeuromPsiquiat (São Paulo) 37:180, 1979.

4. Arlant PA, Gruwnet ML, Heilbrun MP - Primary malignant melanoma of the pineal region. Surg Neurol $7: 121,1977$.

5. Arnvig J, Christensen E - Primary benignant intracranial nelanoma. Acta Chir Scand $82: 217,1939$.

6. Bachtiarow WA, apud Gibson JB et al. 21.

7. Bacchi AK, Sarkar SK, Chakraborti DP, Roy CK - Melanotic spinal schwannoma. Surg Neurol 3:79, 1975. 
8. Bailley $\mathrm{P}$ - Intracranial Tumors. Ed 2. Thomas, Springfield, 1948, pg 152.

9. Beatty TA - Malignant melanoma of the choroid plexus epithelium. J Neurosurg 36:344, 1972 .

10. Bergdahl L, Boquist L, Liliequist B, Thulin C, Tovi D - Primary malignant melanoma of the central nervous system. Acta Neurochir 26:139, 1972.

11. Best PV - A medulloblastoma-like tumour with melanin formation. J Path 110:109, 1973.

12. Bjorkesten GA - Primary melanoma of the leptomeninges. Acta Psychiat 24:307, 1949.

13. Bullard DE, Cox EB, Seigler HF - Central nervous system metastases in malignant melanoma. Neurosurgery 8:26, 1981.

14. Chang P. Hnapper WH - Metastatic melanoma of unknown primary. Cancer 49:1106, 1982.

15. Das Gupta T, Brasfield $\mathrm{R}$ - Metastatic melanoma: a clinicopathological study. Cancer $17: 1323,1964$.

16. Dastur DK, Sinh G, Pandya SK - Melanotic tumor of the acoustic nerve. J Neurosurg $27: 166,1967$.

17. Enriquez R, Egbert B, Bullock $J$ - Primary malignant melanoma of central nervous system. Arch Pathol 95:392, 1973.

18. Fernandez E, Maira G, Puca A, Vignati A - Multiple intracranial metastases of malignant melanoma with long-term survival. J Neurosurg 60:621, 1984.

19. Fischer S - Primary perivascular cerebral, cerebellar and leptomeningeal melanoma. Acta Psychlat Scand 31:21, 1956.

20. Fowler $\mathbf{M}$, Simpson DA - A malignant melanin-forming tumour of the cerebellum. $\mathbf{J}$ Path Bact 84:307, 1962.

21. Gibson JB, Burrows D, Weir WP - Frimary melanoma of the meninges. J Path Bact 74:419, 1957.

22. Hayward RD - Malignant melanoma and the central nervous system. J Neurol Neurosurg Psychiat 39:526, 1976.

23. Hodson $\mathbf{J} \mathbf{J}$ - An intra-osseous tumour combination of biological importance-invasion of a melanotic schwannoma by a adamantinonma. J Path Bact $82: 257,1961$.

24. Humes RA, Roskamp J, Eisenbrey AB - Melanosis and hydrocephalus. J Neurosurg $61: 365,1984$.

25. Lamas E, Lobato RD, Sotelo T, Ricoy JR, Castro $\mathbf{S}-$ Neurocutaneous melanosis.. Acta Neurochir 36:93, 1977.

26. Lesoin F, Leys D, Verier A, Krivosic I, Vaneecloo FM, Jomin M - Je tumeurs mélaniques primitives du systèm nerveux central. Rev Oto-Neuro-Ophtalm 55:143, 1983.

27. Limas C, Tio FO - Meningeal melanocytoma (Melanotic meningioma). Cancer 30:1286, 1972.

28. Madajewicz S, Karakousis C, West CR, Caracandas J, Avellanosa AM - Malignant melanoma brain metastases. Cancer 53:2550, 1984.

29. Mandybur TI - Melanotic nerve sheath tumors. J Neurosurg 41:187, 1974.

30. MeCann WP, Weir BK, Elvidge AR - Long-term survival after removal of metastatic malignant melanoma of the brain. I Neurosurg 28:483, 1968.

31. McNeel DP, Leavens ME - Long term survival with recurrent metastatic intracranial melanoma. J Neurosurg 29:91, 1968.

32. Narayan RK, Rosner MJ, Povlishock JT, Girevendulis A, Becker DP - Primary dural melanoma: a clinical and morphological study. Neurosurgery 9:710, 1981.

33. Negri L - Il melanoma delle molli meningi. Arch De Vecchi 10:965, 1948.

34. Neilson JM, Moffat AD - Hypopituitarism caused by a melanoma of the pituitary gland. J Clin Path 16:144, 1963.

35. Pappenheim E, Bhattacharji SK - Primary melanoma of the central nervous system. Arch Neurol 7:101, 1962.

36. Pasquier B. Couderc P, Pasquier D, Panh MH, Arnoud JP - Primary malignant melanoma of the cerebellum. Cancer $41: 344,1978$.

37. Russel DS, Rubinstein LJ - Pathology of Tumors of the Nervous System. Williams and Wilkins, Baltimore, 1977, pg 55. 